\title{
'Another Voyage': Death as Social Performance in the Major Tragedies of John Webster
}

Near the end of John Webster's The White Devil (1612), the courtier Flamineo is faced with ruin when his patron, Duke Brachiano, is murdered. He responds by forming a suicide pact with his sister, Vittoria, and his mistress, Zanche, but at the last moment the women withdraw from the contract, shoot him, and stamp on his body. The ensuing death scene has all the trappings of a stage villain's final reckoning. Represented throughout the play as a trickster who uses his acting skills in order to rise socially, Flamineo is now 'caught in [his] own engine' (5.6.122), ${ }^{1}$ falling prey to the hypocrisy by which he has lived. Then, suddenly, this moment of retribution is revealed as a parody of the real thing. What seemed Flamineo's final loss of control turns out to be his most darkly witty act of self-assertion when he rises from the dead:

I am not wounded:

The pistols held no bullets: 'twas a plot

To prove your kindness to me and I live

To punish your ingratitude.

Christina Luckyj remarks in her edition of the play that Flamineo's mock death is a 'metatheatrical joke; as Flamineo rises, Webster makes his audience (which has shared the women's illusions) conscious of the reality of the theatre, in which death is always feigned' (5.6.148n). Character and actor wink together at the audience: didn't you know that I was a player? The character has only a few moments to enjoy his triumph, for the play ends with a slaughter from which Flamineo does not rise. Even so, the earlier reminder of the actor's power of resurrection inflects the spectator's reception of these closing fatalities.

As John Dryden noted, 'there are many actions which can never be imitated to a just height: dying especially is a thing which only a Roman gladiator could naturally perform on the stage, when he did not imitate or represent, but do it'. ${ }^{2}$ The last acts of Flamineo and of Webster's other great anti-hero, the assassin Bosola in The Duchess of Malfi, may be read as meditations on the 
meaning of this inevitable failure in mimesis. The lives of these ambitious shape-shifters reflect both early modern culture's attraction to performance as an aid to social advancement and its mistrust of performance as a dangerous lie. By overtly acknowledging the impossibility of representing death onstage, Webster's depiction of their deaths not only accepts the limitations of performance, but also raises the question of its potential in a world where unstable identities are grounded in ceaseless social exchange. Critics have recognized Webster's concern with 'the theatrical nature of personal identity', but by focusing on the playtexts themselves rather than on their embodiment by early modern actors they have tended to validate the despairing moralism of the plays' surviving characters. ${ }^{3}$ The tributes paid to individual performers in the printed versions of Webster's plays may encourage us, instead, to strive to understand how his characters' death scenes may have functioned as theatrical transactions that exposed the tenuous boundaries between character, actor and spectator in a society whose subjects were all performers.

Richard Schechner defines performance as 'twice-behaved behaviour', a citation of actions and gestures that are already established in the cultural imagination but must be constantly reinvented (or 'restored') through the bodies of human beings. ${ }^{4}$ It takes place overtly in theatres where professional actors are paid to entertain spectators with their expert 'restorations' of the behaviours of the real world. But the denizens of the real world are performers, too. They interact in society by citing established gestures for, as Schechner writes, 'the social or transindividual self is a role or set of roles'.5

A similar notion is stressed in the early modern 'Character of an Excellent Actor', often ascribed to John Webster, which appeared in the additions to Thomas Overbury's Characters in 1614. Of his ideal player, the author writes that

All men have beene of his occupation: and indeed, what hee doth fainedly that doe others essentially: this day one plaies a Monarch, the next a private person. Heere one Acts a Tyrant, on the morrow an Exile: A Parasite this man to-night, $\mathrm{t}[\mathrm{o}]$-morow a Precision, and so of divers others. ${ }^{6}$

In this passage, the essence of human identity is seen as lying in the performance of constantly shifting social roles (Tyrant and Exile, Parasite and Precision) by the members of society. The performances of the excellent actor are different from the performances of 'all men' insofar as they are 'fained' rather than 'essential': the actor cites a monarch's behaviours in a controlled environment that defines his gestures as fictional, whereas a real king makes the same actions 
in an environment that defines them as effectual. Even so, the 'Character of an Excellent Actor' stresses the notion that a good actor 'doth not strive to make nature monstrous, she is often seen in the same Scaene with him'. ${ }^{7}$ A good actor 'charmes our attention' because his 'full and significant action of body' closely resembles performances in the real world. ${ }^{8}$

The first published versions of Webster's major tragedies are remarkable for the recognition they grant to the early modern actors who strove to achieve this effect. Although the 1612 quarto edition of The White Devil opens with an address 'To the Reader' in which Webster bitterly assigns the tragedy's theatrical failure to the deficiencies of the Red Bull Theatre, it closes with an authorial tribute to the play's first cast. 'For the action of the play', writes Webster in the final lines he calls 'Instead of an Epilogue',

'twas generally well, and I dare affirm, with the joint testimony of some of [the players'] own quality (for the true imitation of life, without striving to make nature a monster), the best that ever became them: whereof as I make a general acknowledgement, so in particular I must remember the well approved industry of my friend Master Perkins, and confess the worth of his action did crown both the beginning and the end.

Not only does Webster stress the ability of the Red Bull Company to perform a convincing mimesis of life onstage, but he also takes the unusual step of paying individual homage to Richard Perkins, 'the young leading actor of the Red Bull Company', ' for having 'crowned' - that is, ornamented or completed - his play. Since Webster seems to have been extensively, even possessively, involved in the printing of his plays, ${ }^{10}$ it is doubly remarkable that he closes the first quarto of The White Devil by stressing his collaboration with players. He reminds the reader that, without the 'industry' of talented actors like Perkins (and without the audience's approval of it), his tragedy would be unable to show audiences a 'true imitation' of their own experience.

M.C. Bradbrook stresses that this was 'the first time that any individual actor had received such a tribute', and theorizes that 'since he "crowned" both the play's beginning and its end, Perkins had played the Protean Flamineo'. ${ }^{11}$ Although the hypothesis linking Perkins and Flamineo has been contested on historical and textual grounds, ${ }^{12}$ its continuing currency with scholars (5.6.308n) surely attests to the theatrical vitality of Flamineo's part and to the perceived necessity for a great actor's presence in it. The first quarto of The Duchess of Malfi, meanwhile, memorialises individual actors and their roles with even greater specificity, for it contains a list of 'The Actors' Names'. ${ }^{13}$ Again, notes 
Bradbrook, this is 'the first example of such a tribute' in the published corpus of English drama. ${ }^{14}$ The first actor to play Bosola, John Lowin, gets top billing in this remarkable dramatis personae, an honour considering that the next actor listed is Richard Burbage, who played Bosola's master Duke Ferdinand. ${ }^{15}$ Thus, the earliest editions of Webster's major tragedies not only contain exceptional memorials to specific actors, but they appear to pay pointed tributes to actors' performances as murderous anti-heroes. Why might such printed monuments exist, and why might they emphasize such characters in particular? If we wish to understand the links between Flamineo, Bosola and the actors to whom the early playtexts of Webster's tragedies pay special attention, one key characteristic must occupy us. Criticizing early modern English players, I.G. complained that 'they cosen and mock us with vaine wordes, and wee pay them good mony'. ${ }^{16}$ Flamineo and Bosola resemble the actors who played them in this: they, too, strive to achieve monetary gain through deceptive role-playing.

Throughout The White Devil, Flamineo clings to survival and the hope of social advancement by putting on a number of antic dispositions. When he risks apprehension for the murder of Vittoria's husband, he chooses to put on a 'feigned garb of mirth / To gull suspicion' (3.1.29-30). When Vittoria is condemned as a whore, he declares, 'I will feign a mad humour for the disgrace of my sister, and that will keep off idle questions' (3.2.306-7). He establishes an intimate rapport with the theatrical audience, at one point commenting directly on the reasoning behind his histrionics:

It may appear to some ridiculous

Thus to talk knave and madman; and sometimes

Come in with a dried sentence, stuffed with sage.

But this allows my varying of shapes,

'Knaves do grow great by being great men's apes'.

The appearance of an expert actor in a role like Flamineo's, then, provided the early modern theatrical audience with the complex spectacle of a successful player impersonating a man who, like himself, played roles in order to climb the social ladder. ${ }^{17}$

Although The White Devil flopped with audiences at the Red Bull in 1612, the playwright's satisfaction with Flamineo's role may be indicated by the fact that his next play features another leading character whose abilities as a performer become entangled with his determination to 'thrive some way' (1.1.38). Over the course of The Duchess of Malfi, Daniel de Bosola takes up and discards the roles of galley-slave, spy on the eponymous heroine, Master 
of the Horse, melancholy 'court-gall' (1.1.23), hired torturer and assassin, 'common bellman' to the dying (4.2.170), neglected good servant, red hot lover and revenger, among others. Where Flamineo longs for power, Bosola hopes merely to hang on his patron's 'ears like a horse-leech, till I were full, and then drop off (1.1.53-4). Nevertheless, for Bosola as for Flamineo the desire to change social status leads to radical shifts in identity, as he confirms when he describes his deception of his mistress:

A politician is the devil's quilted anvil,

He fashions all sins on him, and the blows

Are never heard; he may work in a lady's chamber,

As here for proof. ...

Now for this act, I am certain to be rais'd,

And men that paint weeds, to the life, are prais'd.

Later, Ferdinand confirms Bosola's implied self-construction as a dangerously gifted mimetic artist, if not his hope to be 'praised' for his mimesis, by comparing him to 'a good actor' who 'is curs'd / For playing a villain's part' (4.2.283-4). As he did with Flamineo, Webster deliberately links Bosola's social-climbing and his misdemeanours to the process of theatrical impersonation. These two characters, otherwise very different, ${ }^{18}$ can be classed together effectively as two knaves who strive to grow great by shifting shapes. ${ }^{19}$

As such, they represent highly controversial images for their audiences. The more conservative strands of social theory in early modern England insisted that upwardly-mobile shape-shifting was inappropriate, and indeed dangerous. As one Sermon published in 1570 asserted, 'Every degre of people, in their vocacion, calling, and office, hath appoynted to them, their duetie and ordre' that must be maintain ed. ${ }^{20}$ However, the ubiquitous use in such documents of words like 'office' tacitly implies that the subject's place in this divinely appointed order is affirmed by his work; he cannot simply be defined by the situation into which he is born, but must actively inhabit his place in the order by performing his 'office'. The instability inherent in such a model of social identity is apparent in Henry Percy's 1609 advice to his son:

There are certain works fit for every vocation; some for kings; some for noblemen; some for gentlemen; some for artificers; some for clowns; and some for beggars; all are good to be known by everyone, yet not be used by everyone. If everyone play his part well, that is allotted him, the commonwealth will be happy; if not then it will be deformed; but which is fit for everyone, quaere? ${ }^{21}$ 
Which, indeed? If the artificer or the clown (the very words for 'craftsman' and 'peasant' sounding all too theatrical) refuses to 'play his part well', deciding that some other 'part' is, in fact, more fitting for him, the established social order may collapse. The very terms of Percy's advice thus threaten to de-essentialize his contention that 'there are certain works fit for every vocation'. The earl's own position at the time of the letter's writing, imprisoned on suspicion of sedition against the King, also does little to support traditional notions of divinely ordained social structure.

By 1609, English society had for some time been the site of social upheaval so profound that the holes in Percy's argument are unsurprising; the traditional positions of gentleman and clown were under serious assault from a number of quarters. As 'exceptionally large numbers' of the old aristocracy fell from power and influence, many subjects from the lower ranks of the gentry and even the mercantile classes strove to better their own situations. ${ }^{22}$ Such social-climbing was symptomatic not simply of vulgar rapaciousness, but often of 'a presumption of national destiny' inculcated into young men at the universities and into other citizens by the diffusion of humanist ideology throughout English society. ${ }^{23}$ By Webster's time, conduct books like The Institucion of a Gentleman (1555), The Courtiers Academie (1598) and The Compleat Gentleman (1622) were used as dictionaries of social behaviour by young men determined to perform their way into high position. ${ }^{24}$ It requires no great stretch of imagination to picture members of that aspiring horde arriving at the playhouse to survey, and perhaps identify with, the fortunes of Webster's social-climbing shape-shifters.

However, the image of performance they would have encountered in The White Devil and The Duchess of Malfi is far from unequivocally rosy. Although Bosola tries 'to define himself as an actor', ${ }^{25}$ he is often alienated from, and by, his own social-climbing theatricality. ${ }^{26}$ As he participates in the Duchess' torture and death, disguise becomes less a source of advancement than a means of escape from his own self-disgust; he tells Ferdinand that he will not see the Duchess again, or at least '[n]ever in my own shape' (4.1.131). Retreating into the strategies of performance, he disguises himself as a tomb-maker and attempts to play out a tale of vanitas mundi designed to mortify the Duchess' aristocratic pride (4.2.174). Struck with guilt after her death, however, Bosola seems to abandon both the means and the ends of his quest for economic security. 'Off, my painted honour!' he cries, rejecting his courtly roles; 'What would I do, were this to do again? / I would not trade my peace of conscience / For all the wealth of Europe' (4.2.330, 333-5). Flamineo, too, suffers moments of profound self-alienation when faced with the fruits of his struggle 
for social success. When his killing of his brother drives their mother mad, she mistakes Flamineo for 'the grave-maker' (5.4.78). Like Bosola, he hides behind his macabre role, muttering, 'So' even as Zanche corrects the mistake: 'Tis Flamineo' (5.4.78-9). Like Bosola, Flamineo in crisis is shocked by the stirrings of some faintly sensed interior reality that rejects the outcomes of his amoral acting: 'I have a strange thing in me, to th'which / I cannot give a name, without it be / Compassion' (5.4.110-12). Even more undermining of performance's social utility than these moments of self-doubt is the simple fact that neither Flamineo nor Bosola actually achieves his goal of self-sufficiency. Despite their virtuoso performances, the final states of these socially ambitious shape-shifters are worse than their first. If they escape poverty and dependence at the end of their respective plays, it is only because both are dead.

Through the figures of Flamineo and Bosola, then, Webster not only depicts the utility of performance in a rapidly shifting world, but also underlines the familiar anti-theatrical trope that conflates acting with socially and spiritually destructive hypocrisy. As the anti-theatrical pamphleteer Stephen Gosson writes, 'for a meane person to take upon him the title of a Prince with counterfeit porte, and traine, is by outwarde signes to show themselves otherwise then they are, and so within the compasse of a lye'. ${ }^{27}$ Flamineo and Bosola certainly 'show themselves otherwise then they are' and tell multiple lies in their determination to avoid the dependence on princes that seems an inescapable part of their social identities. Like the actors who played them on the early modern English stage, they use their ability to appear what they are not in order to become what they are not. Webster's own attitude to such efforts remains equivocal, for he represents his characters' performances as a complicated dialectic between self-fashioning and self-loathing, social advancement and social disgrace - a dialectic that resolves itself in death.

According to one strand of early modern response to death, the encounter with the grim reaper should be a pyrrhic victory for Webster's shape-shifters. After all, both Bosola and Flamineo attempt to erase the supposedly essential difference between aristocrat and servant. Bosola scoffs at mystifications of nobility: 'Some would think the souls of princes were brought forth by some more weighty cause, than those of meaner persons; they are deceived, there's the same hand to them: the like passions sway them' (2.1.104-7). For Sir Walter Raleigh, death is the true proof of this assertion:

It is ... Death alone that can suddenly make man to know himself. He tells the proud and insolent that they are but abjects, and humbles them at the instant.... 
He takes the account of the rich, and proves him a beggar - a naked beggar, which hath interest in nothing but in the gravel that fills his mouth. ${ }^{28}$

John Strode's Anatomie of Mortalitie (1618) agrees: 'There is great difference in men, and greater respect had to some then to others...but when death cometh (as surely it will come to all sorts) then there will be no such difference in the grave'. ${ }^{29}$

Webster's major tragedies, famously applauded by Eliot for their ability to see 'the skull beneath the skin', ${ }^{30}$ likewise illustrate the triumph of death over social place. Death dissolves princes' courts in one fell swoop, as Flamineo observes: 'To see what solitariness is about dying princes. ...O justice! where are their flatterers now?' $(5.3 .43,45-6)$. In The White Devil, the poisoned Brachiano's trembling command, 'On pain of death, let no man name death to me, / It is a word infinitely terrible' (5.3.40-1), attests pathetically to the limits of his aristocratic power. Similarly, the final moments of Ferdinand in The Duchess of Malfi are characterized by the disintegration of his proud aristocratic identity as he recognizes that 'Like diamonds we are cut with our own dust' (5.5.72).

Death's levelling, however, is not really to the shape-shifter's purpose; it simply lands his ambition in the same pit of nothingness to which it consigns his prince's pride. Moreover, death as represented by Raleigh nullifies the very strategies of performance by which Flamineo and Bosola attempt to rise, 'suddenly mak[ing] man to know himself. If death destroys the social barriers that have hindered these characters' advancement, it also precludes any possibility of advancing. As in early modern vanitas paintings and the medieval images of death's triumph to which they look back, death renders rank, riches and the performances by which they might be obtained null and void. Thus, early modern French author Pierre Charron suggests that the hallmark of death is the fact that 'in all the rest a man may be masked, but in this last part, it is to no purpose to dissemble'. ${ }^{31}$ John Donne, upwardly mobile Jacobean courtier turned death-haunted Dean, also describes death in theatrical terms, as 'my play's last scene' 32 Here all performing stops together.

It is unsurprising, then, that when confronting their own deaths both Flamineo and Bosola abjure the histrionic talents by which they waged their social battles. In The White Devil, Flamineo faces the possibility of death by criticizing his own hypocrisy:

I have lived

Riotously ill, like some that live in court;

And sometimes, when my face was full of smiles 
Have felt the maze of conscience in my breast.

Oft gay and honoured robes these tortures try:

'We think caged birds sing, when indeed they cry'.

In The Duchess of Malfi, Bosola, fatally wounded in his struggle with Ferdinand, pushes this association between performance and misery to the point of an implied disavowal of theatricality as a means for social advancement. The terms of this apparent rejection are based in a metatheatrical pun, with the assassin describing himself as 'an actor in the main of all, / Much 'gainst mine own good nature, yet I' th' end / Neglected' (5.5.87-9). His words invoke an essential interior goodness that has been disguised and corrupted by his vicious actions and his feigning. In this context, we may read Webster's portrayals of death as allying him with anti-theatrical condemnations of performance's ruinous effect on identity. 'And thou be what thou canst be', admonishes early modern homilist Thomas White, 'thou losest thy selfe that hauntest those scoles of vice'. ${ }^{33}$ Like Flamineo's court, the theatre and its feignings drag us from our 'good nature' and toward our own destruction, until death comes to call us to account.

Still, readers should beware simplifying the social import of Webster's tragedies, or the vanitas trope to which they so often return. In a culture where aristocrats and intellectuals had themselves painted with skulls to express their piety, intellectual profundity and/or chic, the emblems of death's dominion could also express aspects of worldly identity. ${ }^{34}$ Similarly, Bosola's worldweary pessimism when he dismisses the vanity of his actions does not close off the development of his identity. Even as he speaks those words, Bosola remains engaged in social struggle. Not only is he still complaining of being unfairly 'neglected', but he is also in the process of re-inventing himself as the Duchess' revenger (5.5.80-1), fashioning a new persona through which he may perform his 'good nature' as well as his talent for murder. Searching for novelistic psychological consistency in Webster's tragedies, Michael Cameron Andrews dismisses this new persona as simple 'self-deception': if the character's earlier guilty confessions are true, then these declarations of goodness must be false. ${ }^{35}$ His view validates the Marquis of Pescara's condemnation of Bosola as merely a 'wretched thing of blood' (5.5.91). But if, instead, we read these lines in the context of the early modern theatre, where actors were admired for their ability to 'effect sudden, highly visible transitions between passions in the length of a speech or a single line', ${ }^{36}$ we may discover a Bosola whose effect on his spectators is far more complex than his effect on Pescara. 
In such a reading, Bosola's shifts between personae are parallel to those of a virtuoso actor, openly displayed in order to make an impression on an audience. Because they take place as he is dying, they can be viewed as a last attempt to shape the opinions of his spectators both onstage and off. This interpretation squares with other, non-dramatic early modern texts that show the dying subject making a final bid for social power through a brilliant 'restoration' of established images of a good, moving, or socially efficacious death. Here, death appears not only as the annihilation of the self, but also as a new stage in the history of the self's impact on the world around it.

In his pamphlet $A$ Christall Glasse for Christian Women, for example, the devoutly protestant Philip Stubbes, a man virulently opposed to the fainings of the professional theatre, is happy to represent his wife Katharine's dying moments as an edifying performance. In Stubbes' account, Katharine literally 'restores' her saviour's behaviours with her own body; when she declares that 'Christs armes were spred wide open... upon the Crosse', she illustrates her point by 'spred[ing] her own armes'(C3r). ${ }^{37}$ She interprets the meaning of her death's spectacle to the assembled audience: 'Right worshipfull and my good neighbours and friends, ... for that my houre-glasse is runne out, and that my time of departing hence is at hande, I am perswaded...to make a confession of my fayth before you all'(B1r). According to Philip Stubbes' version of his wife's words, this final confession is designed not only to ensure the immortality of her soul, but also to guarantee the earthly survival of her reputation as 'a perfect Christian' and to allow others to 'learne what the Spirit of God hath taught me' (B1r). If Katharine Stubbes is unlikely to rise from the dead, Flamineo-style, except in the next world, her persona as a model for Christian womanhood will remain socially influential.

Even more strikingly performative is the last speech of the Jesuit Robert Southwell, condemned to execution in 1595. In his biographer's account, Southwell addresses witnesses of his execution through a theatrical metaphor:

I am come hither to play out the last act of this poor life. ... This is my death, my last farewell to this unfortunate life, and yet to me most happy and most fortunate. I pray it be for the full satisfaction of my sins, for the good of my Country, and for the comfort of many others. Which death, albeit that it seem here disgraceful, yet I hope that in time to come it will be to my eternal glory. ${ }^{38}$

Southwell's execution is a drama staged by the state authorities in which the Catholic's dismembered body will demonstrate the hegemony of the dominant order. However, just as Flamineo reminds his audience not to be too quick to 
judge his performances 'ridiculous' (4.2.239), Southwell insists that his death may only seem 'disgraceful'. Southwell's speech re-frames the spectacle of his suffering as one 'most happy and most fortunate' to him, not only because it may guarantee his 'eternal glory' or spiritual immortality, but also because he hopes it will have lasting social power 'for the good of [his] country, and for the comfort of many others'. The anecdotes of Southwell's Catholic biographers focus on the dying man's impact on his audience; they proudly report that Southwell's courage moved the Protestant Lord Mountjoy to remark, 'I cannot answer for his religion, but I wish to God that my soul may be with his'. ${ }^{39}$

As this emphasis attests, the social influence achieved by dying individuals like Katharine Stubbes and Robert Southwell is ambiguous. It depends not only on their performances, but also on the reactions of their spectators, who must themselves choose to perform and 'restore' the behaviours of the departed if those behaviours are to survive. Although the 'achievement of a 'good' death transform[s] the process of dying from tragedy into triumph', the dying subject can never be sure of such triumph because both 'the individual at the centre of the drama and the members of the audience' have to play their parts if the performance is to succeed. ${ }^{40}$ Although Stubbes and Southwell represent opposite sides of the early modern English Christian spectrum, both can die with the assurance that at least some of their spectators share their religious commitments and will thus assure the survival of their behaviours. But what of a death that, like Flamineo's or Bosola's, emphasizes only the dying subjectivity itself? Historian Ralph Houlbrooke describes defiant early modern criminals who planned their own deaths, 'seeking at all costs to appear cheerful and debonair [and presenting]... a performance of studied, stylish nonchalance'. ${ }^{41}$ How might such stylish, solipsistic performances actually affect their audiences and change spectators' actions?

With its visible turns between world-weary repentance and defiant self-assertion, Bosola's death scene in The Duchess of Malfi explores this very question. Webster takes pains to ensure that the theatrical audience is acutely aware of watching, not the 'real' death of a felon, but an artful imitation of such a death. The dying Bosola not only refers to himself as an actor, but also describes his murder of Antonio as '[s] uch a mistake as I have often seen / In a play' (5.5.94-5). As Berry argues, this reference 'seeks to jar the audience from its involvement in the play as an imitation of life'. ${ }^{42}$ Such a strategy diffuses any anxiety the audience may feel at its potential sympathy for a dying assassin; that emotion might be questionable in the execution yard but is permissible in a theatre where spectators know that they are only watching a 
feat of impersonation. On the other hand, Webster's metatheatricality tacitly invites the audience to identify with Bosola, for they, too, are playgoers watching mistakes onstage. ${ }^{43}$ Like the spectators at the deaths of Katharine Stubbes and Robert Southwell, Bosola's audience is asked to recognize its kinship with the dying figure who performs for their benefit.

The performance itself is full of contradictions. At last gasp, Bosola cries,

Oh, I am gone:

We are only like dead walls, or vaulted graves

That, ruin'd, yields no echo. Fare you well;

It may be pain: but no harm to me to die

In so good a quarrel. Oh this gloomy world,

In what a shadow, or deep pit of darkness

Doth, womanish, and fearful, mankind live?

Let worthy minds ne'er stagger in distrust

To suffer death or shame for what is just:

Mine is another voyage.

Although Neill describes this speech as Bosola's ultimate 'surrender to the utter indifference of the earth', ${ }^{44}$ the dying assassin actually shifts shapes here as rapidly as at any point in the play. His despairing contention that 'we are only like dead walls, or vaulted graves' is undercut by his next assertion: '[i]t may be pain: but no harm to me to die / In so good a quarrel'. Here again we find Bosola performing himself as his Duchess' avenger rather than her murderer. On the verge of his own dissolution he has destroyed his aristocratic masters and identified himself with his mistress' cause, constructing an identity which will raise him from the level of suborned hit man to a position at once higher and more socially subversive.

At the conclusion of his dying speech, Bosola shifts shapes once more, differentiating himself not only from the perversity of Ferdinand but also from those confidently 'worthy minds' incapable of such evil. His earlier depiction of himself as a dead wall has suggested the failure of his social performances. Concretely speaking, he has accomplished nothing, and Delio, the virtuous spectator figure at his death, goes some way toward re-absorbing him into conventional moral discourse when he remarks that such men leave 'no more fame behind 'em, than should one / Fall in a frost, and leave his print in snow' (5.5.113-14). Neill sees only the play's virtuous characters (and, by extension, the playwright who memorialises them) as surviving this holocaust of identities. ${ }^{45}$ Clearly, Bosola has not reached such a point of eternal stability; Whigham describes his departure as 'seaward, to the galleys, 
to the pathless wilderness from which he entered the play, a castaway looking for solid ground to call his own'. ${ }^{46}$ Still, if Bosola's last role is that of an unfixable traveller, his last performance is a cliffhanger that offers no final word on his life's meaning. He does not remark, 'Mine was another voyage', but journeys into death in the present tense, projecting himself past the ending of the play.

The theatrical effect of this strategy is illuminated by the second, 'real' death of Flamineo in The White Devil. The dying Flamineo's speeches are riddled with sententiae that resemble Delio's - and Raleigh's - remarks on the futility of earthly glory. "This busy trade of life appears most vain", he declares, "Since rest breeds rest where all seek pain by pain"” (5.6.271-2). Jonathan Dollimore argues that these words, which he describes as Flamineo's 'last', ${ }^{47}$ allude to Francis Bacon's essay Of Great Place, where Bacon writes:

It is a strange desire, to seek power and lose liberty; or to seek power over others and lose power over a man's self. The rising unto place is laborious, and by pains men come to greater pains; and it is sometimes base, and by indignities men come to dignities. The standing is slippery, and the regress is either a downfall, or at least an eclipse, which is a melancholy thing. Cum non sis qui fueris, non esse cur velis vivere [When you are no longer who you have been, there is no reason why you should wish to live]. ${ }^{48}$

Dollimore sees this potential reference to Bacon's essay as exemplifying 'the play's sense of how individuals can actually be constituted by the destructive social forces working upon them'. ${ }^{49}$ The dying sinner turns against himself, recognizes the futility of his shape-shifting and reinscribes himself into an immutable social order.

However, the force of Flamineo's moribund moralism is somewhat undercut by the fact that he has already appropriated similar tropes of doom to grace his fake death earlier in the scene. ${ }^{50}$ If these tropes point to the determination of Flamineo's identity by social forces, they also point to his continuing renegotiation of those forces through his mockery of social clichés. Like Bosola, the dying Flamineo is still a master actor struggling to impose his own identity on those around him. His despairing borrowing from Bacon is not, in fact, his last word. Rather, that involves a grand theatrical gesture that recalls his earlier, gleeful shape-shifting. 'Let no harsh flattering bells resound my knell', Flamineo bids some transcendent stage-hand: 'Strike thunder and strike loud to my farewell' (5.6.273-4). This last act of self-assertion contradicts the fatalism that precedes it, for if it refuses the flattery of the church 
bells that would muffle the shape-shifter's sins, it also demands in honour of Flamineo's death 'a prodigious sign associated with the fall of great men', thunder (5.6.274n).

The fact that these final lines constitute a defiant performance of self has long been recognized, but the extent of their metatheatricality has not. ${ }^{51}$ Thunder appears to have been one of the more common sound effects in the early modern English theatre, perhaps achieved by rolling a cannon ball along bumpy boards; in Every Man in His Humour, Ben Jonson mentions 'roll'd bullet heard / To say, it thunders' (Prologue, 18-19). ${ }^{52}$ When he calls for thunder in The White Devil, Flamineo may be seen as cuing the playhouse sound crew with his last breath. In a play whose opening scene compares princes to 'violent thunder' (1.1.11), his demand asserts not only his control over the theatrical space, but also his identification with nobility. Dollimore argues that Flamineo sustains his moribund defiance 'only by isolating himself in the moment removed from the past, the future, almost from consciousness itself;'53 Flamineo's demand for thunder, however, is a social gesture which situates him firmly in the playhouse, negating his isolation and projecting him on 'another voyage' into the future.

The aims of that voyage are clarified by Flamineo's other snippet of metatheatrical black humour. 'I have caught / An everlasting cold', he cries; 'I have lost my voice / Most irrevocably' (5.6.268-9). This quip distinguishes his 'real' death from his faked one (where no jokes were allowed to spoil the heroic style); even as his blood pours out, Flamineo's trademark irony is alive and well. Moreover, like Bosola's reference to 'such a mistake as I have often seen in a play', Flamineo's joke reminds the audience that the blood is fake and the death not 'real' at all. We are in the theatre, where death is always an illusion and where any actor might be a little hoarse after an afternoon of belting lines into the crowd. The actor's loss of voice, the end of the performance, is the tragic character's loss of body, the end of his life. Flamineo's evocation of this reality may be read as enforcing the difference between actor (who will speak again another day) and character (who will not) ${ }^{54}$ However, one may also interpret it as a sly reference to the fact that Flamineo is a fictional character whose role may be played again and again and whose loss of voice, like the actor's, is thus not 'irrevocable' at all.

In short, the death scenes of Flamineo and Bosola call upon the theatrical audience to remember and even to rethink the player's relationships with the character he plays and with the spectators themselves. Joseph Roach has argued that actors serve their communities as effigies onto whom anxieties about identity can be projected. 'Performed effigies', he writes, 'provide 
communities with a method of perpetuating themselves through specially nominated mediums or surrogates'; 55 '[ $\mathrm{t}]$ he passage between life and art, identity and role [is] enacted by their bodies as a condition of their employment'. ${ }^{56}$ Actors help audiences understand and inscribe their cultures' precariously drawn distinctions between truth and falsehood, reality and performance, even life and death. They do so by crossing and even blurring those lines: playing riveting death scenes, for example, so that the audience can contemplate death in an environment where 'real' death is absent. The whole risky transaction rests on another set of boundaries: those between character (who 'really' dies) and actor (who only pretends to do so), and those between actor (who crosses boundaries by pretending to be someone else) and the spectators (who only watch these crossings).

The nods to individual players in the printed texts of Webster's major tragedies recognize the actor's crucial role in creating 'the true imitation of life', the primary form of theatrical boundary-crossing. But the metatheatrical death scenes that concern us here go further. When Flamineo complains of his loss of voice and calls for thunder, they evoke and call into question the traditional boundary between character and actor. When Bosola remarks that Antonio's death was 'such a mistake as I have often seen in a play', they blur the distinction between character and spectator. Such moments remind the audience that these characters, the actors who play them and the spectators who watch them are all involved in the creation of performance.

What are the social ramifications of such boundary-crossings? Some of the recorded reactions to the acting of the period's most famous player, Richard Burbage, may help us to answer this question. One of Burbage's elegists describes the effect of his performance of Hamlet's death: 'Th[e] spectators, and the rest / Of his sad Crew, whilst hee but seem'd to bleed, / Amazed, thought even then he died in deed'. ${ }^{57}$ So powerful is Burbage's 'seeming' death that the boundary between the famous, living actor and the dying Prince of Denmark disappears. Similarly, one of Thomas May's characters in The Heir describes 'a player' who clearly recalls Burbage in his famous role of Hieronimo in The Spanish Tragedy:

I have seen the knave paint griefe

In such a lively colour, that for false

And acted passion he has drawne true teares

From the spectators eyes, Ladyes in the boxes

Kept time with sighes, and teares to his sad accents

As had he truely bin the man he seemd. ${ }^{58}$ 
The great actor can control his audience's emotions, convincing them to repay his false tears with true ones. He achieves a version of the social effect Katharine Stubbes and Robert Southwell aimed for: changing his viewer's behaviours, their performances, through his acting. In this context, an actor playing one of Webster's shape-shifters might gain power over his audience's reactions by giving a moving rendition of his character's final lapse into powerlessness, just as Flamineo gains power over Vittoria and Zanche's behaviour by giving a convincing rendition of his own death. In The White Devil and The Duchess of Malfi, Webster complicates this transaction at the very height of potential mimetic rapture, using metatheatricality to remind spectators that it is performance that so transfixes and transforms them. Such moments risk angering spectators who feel bilked of their beloved illusion, but they also validate theatricality as a social tool accessible to the audience as well as to the character and the actor.

Perhaps the best way of resolving the ambiguities raised by the death scenes of Flamineo and Bosola is to say that the social power of performances of death, as of performances in death, lies precisely in their destruction of stable worldly identities. Death demonstrates the finitude of any human identity, so that Bosola can glory that the Cardinal, who 'stood...like a huge pyramid / Begun upon a large and ample base, / [Shall] end in a little point, a kind of nothing' (Duchess 5.5.76-8). Flamineo responds to Ludovico's frustrated demand that he reveal what he is thinking:

Nothing, of nothing: leave thy idle questions;

I am i'th'way to study a long silence.

To prate were idle I remember nothing.

There's nothing of so infinite vexation

As man's own thoughts.

Vanity of vanities, all is vanity; no human position can survive the hand of eloquent, just, and mighty death. Hence, little Giovanni, the new Duke of Bracchiano, declares that the deaths of Flamineo and Vittoria should make 'guilty men remember their black deeds / Do lean on crutches, made of slender reeds' (5.6.298-9), and Delio dismisses the idea that those who are not 'lords of truth' can have any true impact on those who come after them. With such words, the onstage spectators at the deaths of Webster's shape-shifters stress the finitude and fragility of all social-climbing performances.

However, the final performances of Flamineo and Bosola are not directed only at these nay-sayers. Instead, in his final moments each character demands that the offstage audience perceive both his undimmed capacity for shape- 
shifting and the fact that he is being played by an actor who shares that capacity and who will live to make money from it another day. If identities really are unstable and if the actors who played Flamineo and Bosola were as compelling as the recognition accorded them in the early editions of Webster's tragedies suggests, they could have moved spectators to identify with the ambitions of the characters they played and to experiment with using performance as a social tool. In the Anatomie of Abuses, Philip Stubbes worries that the power of such transactions will encourage spectators to imitate characters' transgressive actions, 'to playe the hypocit: to cog, to lie and falsify': all skills dangerously useful to the social-climbing that Stubbes so abhors. ${ }^{59}$ If we take Webster's metatheatricality seriously in its theatrical context, we may find ourselves inclined to take Stubbes' argument a little more seriously as well. As the author of A Christall Glass for Christian Women, Stubbes understood the impact that performance can achieve on its spectators, even after the performer appears to have died.

As Dryden believed, death is the least theatrically imitable of all experiences, for it is the moment that finally removes the subject from the social intercourse on which theatrical representation depends. Nevertheless, the exchange between a dying person and those who live on after his or her death may be the social transaction that most closely approximates the impact of a powerful actor's performance on the spectators who leave the theatre after the last words have been spoken. Like the men and women whose words are recorded in early modern records of death, the actor has a supreme but fleeting opportunity to impress his audience with an image of human identity and to show them how their own performances of self might be affected by that image. In the theatre as in the death-chamber or at the scaffold, only the reactions of individual spectators can determine the ultimate success or failure of the performance.

In the final moments of Webster's major tragedies, his shape-shifters are dismissed as mere malefactors, but the playwright's metatheatricality opens a path by which their transgressive dream of self-transformation might slip off the stage and into the imaginations of those in the audience who are willing to receive it. If performance fails as a means to a determinate end within the narratives of Webster's plays, it may have succeeded as a constitutive force in the culture that performed and watched them. The deaths and resurrections of Webster's shape-shifters suggest that even if Francis Bacon was right about the rise and fall of great men, his words do not apply to relationships within the theatre. Perhaps, onstage, characters who serve as surrogates for the riskiest dreams of the cultures that create them can only continue to live when they 
are no longer who they have been. They die as characters, but they help to shape the identities of actors and spectators. They die, but their Protean struggle to create new social possibilities for themselves departs - on another voyage.

\section{Notes}

This essay could not have been written without the exceptional intellectual and personal generosity of Christina Luckyj, who supervised its first incarnation. I am also most grateful to Ron Huebert and Martin Wiggins for their vital and ongoing contributions to my understanding of Webster's work. Shannon Brownlee and David Nicol read multiple drafts of this essay and offered invaluable advice. Finally, I should like to thank those who heard and commented perceptively on earlier versions of this work: Kim Solga, Jenn Stephenson and the participants in the 'Performative Resurrections' Conference at the Graduate Centre for the Study of Drama, University of Toronto; and the members of the Early Modern Studies Society of the University of King's College.

1 Christina Luckyj (ed), The White Devil: John Webster (London, 1996). All quotations from the play and references to Luckyj's notes are taken from this edition.

2 John Dryden, An Essay of Dramatic Poesy, Thomas Arnold (ed) (Oxford, 1918), 48.

3 Andrea Henderson, 'Death on the Stage, Death of the Stage: The Antitheatricality of The Duchess of Malfi, Theatre Journal 42.2 (May 1990), 194.

4 Richard Schechner, Between Theatre and Anthropology (Philadelphia, 1985), 36-7.

5 Schechner, Between Theatre and Anthropology, 36.

6 John Webster, (?)'The Character of an Excellent Actor', in The Complete Works of John Webster, Vol. 4, ed F.L. Lucas (Boston, 1927), 42.

7 Webster, 'Character', 42.

8 Webster, 'Character', 42.

9 M.C. Bradbrook, John Webster: Citizen and Dramatist (New York, 1980), 119.

10 As D.C. Gunby remarks in his Introduction to John Webster: Three Plays (Harmondsworth, 1972), 31, 'all the evidence points to Webster's active participation in the production of the Quartos [of his tragedies]'. Most famously, the title page of Q1 Duchess of Malfi declares that it contains the 
'perfect and exact Coppy, with diuerse things printed, that the length of the play would not beare in the Presentment'. (See John Webster, The Duchess of Malfi, ed Elizabeth M. Brennan, $3^{\text {rd }}$ edition (1964; London, 1993), 1. All subsequent references to the play and to Brennan's notes will be to this edition.) Henderson, 'Death on the Stage, Death of the Stage', takes this as evidence that the play ' is in fact anti-theatrical and reflects a movement toward a literary culture which privileges private reading'. She also adduces John Ford's praise to the play as coming 'from Webster's 'clear pen' - not from their actors on stage' (206). However, she ignores not only the list of 'The Actors' Names', but also the title page's boast that the play was 'Presented privately, at the Black-Friers; and publiquely at the Globe, By the Kings Maiesties Seruants'; William Rowley's reference to the day when Webster's Duchess was 'lively body'd' on stage (prefatory verse, 'To his friend Mr John Webster Upon his Duchess of Malfi', in Brennan's edition, 7, line 5); and Thomas Middleton's rhetorical praise for the play's performance: 'For who e'er saw this Duchess live, and die, / That could get off under a bleeding eye?' (prefatory verse, 'In the just worth, of that well deserver Mr. John Webster, and upon this masterpiece of tragedy', in Brennan's edition, 6, 11.18-19). Clearly, theatrical performance was at least as important to Webster and to his admiring peers as private reading.

11 Bradbrook, John Webster, 120.

12 Martin Wiggins objects to it on the grounds that 'Perkins is not known to have played another leading role until after 1626' (Journeymen in Murder: The Assassin in English Renaissance Drama (Oxford, 1991), 172). He suggests that Webster's mention of 'the beginning and the end' more likely refers to the smaller but vital part of the assassin Ludovico, who speaks the play's first word and its penultimate speech. The argument over the role in which Perkins merited Webster's praise is unlikely to be solved unless further playhouse documents surface. In the argument that follows, I read Perkins as Webster seems to have done, not only as a 'worthy friend' but also as an image of his ideal: the 'excellent actor' who could 'crown' a playwright's work. Whether or not Perkins actually played Flamineo, it seems safe to assume that Webster would have wished to see just such an 'excellent actor' in the role.

13 This list does not appear in Q2; Brennan reproduces it in her edition, 3.

14 Bradbrook, John Webster, 143.

15 In The Best Actors in the World: Shakespeare and his Acting Company (Westport and London, 2002), 192-3, David Grote notes that as Lowin's career progressed he played 'a succession of rotund older soldiers who are often described as 'merrie', a common indication of a man fond of his liquor. He would also 


\section{Roberta Barker}

later be associated with Falstaff'. Although an ex-soldier, the melancholic Bosola is a relatively 'surprising' role for such an actor (193). The fact that Lowin merited top billing in the published list of actors' names in such an unaccustomed part may be a sign that he played it with the virtuosity I imagine below. Perhaps he also brought some of the humour and charm of his merrier roles to the melancholic 'court gall', thereby increasing the character's attraction for the audience.

16 I.G., A Refutation of the Apology for Actors (London, 1615), sig.I1r.

17 Peter Thomson, 'Webster and the Actor', John Webster, ed Brian Morris (London, 1970), 41.

18 See Wiggins, 173, for a cogent discussion of the dangers of classing Flamineo and Bosola too easily together. For the purposes of this essay, I discuss their similarities as 'player' figures, but do not wish to imply that they are reducible simply to equivalent 'malcontents' or 'tool villains'.

19 Ralph Berry, in The Art of John Webster (Oxford, 1972), 33, similarly argues that Flamineo and Bosola are both primarily role-players, but does not link this aspect of their characters to the social position of the actors who originally played them.

20 'An Exhortacion Concernyng Obedience', Certayne Sermons, or homelies, appointed by the kynges Majestie, to bee declared and redde, by all persones, vicars, or curates, every Sondaye in their churches, where they have cure (London, 1547), $\mathrm{R} 1^{\mathrm{r}}$.

21 Cited in L.C. Knights, Drama and Society in the Age of Jonson (1937; London, 1951), 148.

22 Lawrence Stone, The Crisis of the Aristocracy, 1558-1641 (Oxford, 1965), 83.

23 Frank Whigham, Ambition and Privilege: The Social Tropes of Elizabethan Courtesy Theory (Berkeley, 1984), 13.

24 See Whigham, Ambition and Privilege, 20 passim.

25 Henderson, 'Death on the Stage, Death of the Stage', 201.

26 Frank Whigham, 'Sexual and Social Mobility in The Duchess of Malfi, PMLA 100 (1985), offers the most detailed reading of Bosola's roles as 'marked by alienation' (176). Henderson, too, remarks that Bosola 'ends up dividing himself in two, becoming both actor and spectator, and observing himself as a mere actor in moments of crisis' (201).

27 Stephen Gosson, Plays Confuted in Five Actions (London, 1582; London, 1972), 5.

28 Sir Walter Raleigh, Selected Prose and Poetry, ed Agnes M.C. Latham (London, 1965), 203-4. 
29 George Strode, The Anatomie of Mortalitie (London, 1618), E2v'.

30 T.S. Eliot, 'Whispers of Immortality', in The Collected Poems 1909-1962 (San Diego, 1963).

31 Pierre Charron, Of Wisdome Three Bookes, trans Samson Lennard, $2^{\text {nd }}$ edition (London, 1630), 346.

32 John Donne, 'Divine Medititation 6: 'This is my play's last scene" in The Complete English Poems, ed A.J. Smith (1971; Harmondsworth, 1986), 311.

33 Cited in E.K. Chambers, The Elizabethan Stage, Vol.4 (Oxford, 1923), 197.

34 In Death and Elizabethan Tragedy: A Study of Convention and Opinion in the Elizabethan Drama (New York, 1960), 36, Theodore Spencer mentions Holbein's lavish portrait of The Ambassadors in this connection: 'Holbein doubtless saw nothing but propriety in the fact that having painted the magnificent dress of his ambassadors, he should put a skull at their feet'. 'The fashion of including skulls in portraits', he adds, 'lasted well into the seventeenth century'.

35 Michael Cameron Andrews, This Action of our Death: The Performance of Death in English Renaissance Drama (Newark, 1989), 71.

36 Joseph Roach, The Player's Passion: Studies in the Science of Acting (Newark, 1985), 42.

37 Philip Stubbes, A Christall Glasse for Christian Women (London, 1600).

38 Cited in Christopher Devlin, The Life of Robert Southwell, Poet and Martyr (London, New York and Toronto, 1956), 321, 322. Devlin notes that his account of Southwell's death and last words is taken from a number of manuscript sources from the period, many of them held at Stonyhurst (358).

39 Cited in Devlin, 324.

40 Ralph Houlbrooke, Death, Religion, and the Family in England, 1480-1750 (Oxford, 1998), 188.

41 Houlbrooke, Death, Religion, and the Family, 215.

42 Berry, The Art of John Webster, 34.

43 Andrews objects that '[o]n the basis of extant Renaissance plays, it is hard to give credence to his assertion that comparable blunders 'often' occurred in pre-Websterian drama' (71). I would argue that Bosola's words are intended not as a commentary on the plot machinations of Webster's contemporaries, but rather as a moment of mise-en-abyme designed to remind the theatrical audience that they are watching a play in which the mistake in question has just occurred.

44 Michael Neill, Issues of Death: Morality and Identity in English Renaissance Tragedy (Oxford, 1997), 346. 


\section{Roberta Barker}

45 Neill, Issues of Death, 352.

46 Whigham, 'Sexual and Social Mobility', 181.

47 Jonathan Dollimore, Radical Tragedy: Religion, Ideology and Power in the Drama of Shakespeare and His Contemporaries (Chicago, 1984), 245.

48 Francis Bacon, 'Of Great Place', in The Essays, John Pitcher (ed) (Harmondsworth, 1985), 90. These lines are cited in Dollimore, 245-6.

49 Dollimore, Radical Tragedy, 246.

50 For instance, during his mock death Flamineo howls, ' $\mathrm{O}$, the way's dark and horrid! I cannot see' (5.6.136), matching and/or undercutting his moan, 'O, I am in a mist' (5.6.258) during his 'real' death.

51 See Andrews, This Action of our Death, 62.

52 Ben Jonson, Every Man in His Humour, ed J.W. Lever (Lincoln, 1971).

53 Dollimore, Radical Tragedy, 245.

54 In this vein, Jacqueline Pearson asserts in Tragedy and Tragicomedy in the Plays of John Webster (Manchester: MUP, 1980), 78, that 'the identity which the actor normally sheds as the curtain finally goes down Flamineo begins to shed rather earlier'.

55 Joseph Roach, Cities of the Dead: Circum-Atlantic Performance (New York, 1996), 36.

56 Roach, Cities, 78.

57 Cited in Andrew Gurr, The Shakespearean Stage, 1574-1642, 2 $2^{\text {nd }}$ edition (Cambridge, 1980), 111.

58 T.M. (Thomas May), The Heire: An Excellent Comedie (London, 1622), B1r.

59 Philip Stubbes, The Anatomie of Abuses, ed M.J. Kidnie (Tempe, Arizona, 2002), 204. 